\title{
Enrichment Characteristics of Heavy Metal Cadmium in Woody Plants System ${ }^{* *}$
}

DOI: $10.15255 /$ KUI.2014.033

KUI-17/2015

Preliminary communication Received December 31, 2014 Accepted March 18, 2015

J.-X. Yang, X.-L. Li, Y.-B. Hu, L.-M. Gao, and D.-X. Yao

The School of Earth and Environment, Anhui University of Science and Technology, 232001 Huainan Anhui, PR China

\begin{abstract}
\| Abstract
In recent years, extensive research has been done on phytoremediation technology, but the study on repair mechanisms and the migration path of heavy metal contaminants in woody plants is particularly rare.

The object of this study was Pan Yi mine reclamation area in Huainan as an example of cadmium (Cd) content within different parts of woody plants tissue. Based on the research findings about the migration path, the paper uses statistical methods to carry out the analysis by multiple models. Statistical methods applied multiple trend analysis: linear and logarithmic, and also conic, cubic, and compound curve, power exponent, S curve, growth and exponential regression model. The findings show that $\mathrm{Cd}$ is enriched along the root-stem-branch-leaf path in woody plants system in the form of cubic curve, i.e. $y=b_{3} x^{3}+b_{2} x^{2}+b_{1} x+b_{0}$. The findings reveal that the enrichment capability of $\mathrm{Cd}$ in various parts of the same species of woody plants is different and this is also the case in different species.
\end{abstract}

$\|$ Keywords

Heavy metals, Cd, woody plants, enrichment characteristics

\section{Introduction}

When entering the environment, heavy metals only change their morphology and valence. They cannot be degraded biologically and are difficult to purify. In recent years, many scholars have focused on phytoremediation and have carried a great amount of research on it, especially from the aspect of absorption, accumulation, transformation and ecological effects of heavy metals in crops, vegetables and other economic plants. ${ }^{1-2}$ But the main object of these studies was mainly based on herbaceous plants, and the study on repair mechanisms and migration law of heavy metal contamination of woody plants is particularly rare. ${ }^{3}$

At present, the domestic and foreign study on the absorption of heavy metals in woody plants is only restricted to the research on absorption, migration and accumulation of hyper-accumulator plants and the basic mechanism of tolerance of heavy metals, and the study has only just started. ${ }^{4}$ T. Punshon, N. W. Lepp and N. M. Dickinson developed a hydroponic screening method and screen willows resistant to $\mathrm{Cu}^{5}$. T. Granel, B. Robinson, and T. Mills conducted experiments on potted willows in New Zealand and found that the average concentration of $\mathrm{Cd}$ accumulated in the leaves of shrub willows based on clonal growth is $1.5-10 \mathrm{mg} \mathrm{kg}{ }^{-1} .{ }^{6}$ G. Y. Yu, Y. N. Wu, and X. Wang studied the transferring and cycling of heavy metals in and out of Poplar trees before and after their leaves fall, and found that accumulation of $\mathrm{Cd}$ and $\mathrm{Hg}$ in them as a fast-growing

\footnotetext{
Corresponding author: Xiao Long Li

E-mail: xlli@aust.edu.cn

** Supported by the provincial outstanding young talent fund project in 2012 (2012SQRL054)
}

species of trees reaches $34.93 \mathrm{mg} \mathrm{kg}^{-1}$ and $47.19 \mathrm{mg} \mathrm{kg}^{-1}$. $^{7}$ X. Li, D. M. Xu and Y. C. Zhao studied distribution of heavy metals in the cover soil and vegetation of household refuse landfills, and they found that the maximum value of $\mathrm{Cu}$ concentration in roots, stems and leaves of woody plants represented by Euonymus japonicus is about four to eight times greater than that of the concentration in corresponding parts of the reference samples, and roots of woody plants have stronger enrichment ability of heavy metals than herbs. ${ }^{8-10}$

The paper, taking Pan Yi mine reclamation area in Huainan as an example, adopts statistical methods to make the analysis based on screening different woody plants growing well. According to the findings of $\mathrm{Cu}$ content of different parts in woody plants, it analyses the transference and distribution laws of the heavy metal $\mathrm{Cu}$ in different parts of woody plants by using the multiple model trend analysis method in order to search enrichment characteristics of the $\mathrm{Cd}$ in woody plants and provide a scientific basis for repairing time of soil heavy metal pollution in coal mine reclamation areas. Meanwhile, it provides some ideas and methods for the quantitative study of the transference and accumulation process of $\mathrm{Cd}$ in woody plants as well as for the quantitative calculation of reasonable choice of models. ${ }^{11-13}$

\section{Materials and methods}

\section{Study areas overview}

Pan Yi mine reclamation area in Huainan is located in an alluvial plain in China, the terrain of which is flat. Its 
surface elevation is from $+17.5 \mathrm{~m}$ to $+23.5 \mathrm{~m}$, which is generally high in North, low in South East, high in West and low in East. After more than 20 years of mining, the terrain of Pan Yi mine has changed greatly, featuring many collapsed ponding areas and pits on the earth's surface of mine goaves. In 2005, Huainan Mining Group carried out the geological environment governance project of mines. The project adopts the method of stripping topsoil, backfilling waste rock and overlying clay craft. The depth of the cover soil is about $80 \mathrm{~cm}$, and the collapsed areas through governance reach 37.96 hectares. Furthermore, planting forest areas are near one hundred acres. ${ }^{14-15}$

\section{Sample collection}

In the Pan Yi reclamation areas, 50 trees among four widely distributed tree species with good growth, including Poplar, Ligustrum lucidum, Sichuan juniper, and Cedrus deodara are screened as the study objects. Among them, roots $(10 \mathrm{~cm})$, stems $(30 \mathrm{~cm})$, stems $(120 \mathrm{~cm})$, branches $(150 \mathrm{~cm})$ and leaves $(180 \mathrm{~cm})$ are respectively collected. Because the rhizome of Sichuan juniper is not easy to collect, it is replaced by collecting stems $(100 \mathrm{~cm})$, which are placed in the sample bag for the determination.

\section{Pre-treatment and tests of samples}

According to the research purpose, plant samples were treated in their different parts. Firstly, the samples were washed with tap water to remove the dust, dirt and other debris. They were rinsed twice with deionized water. Naturally dried, the samples were cut up with a stainless steel knife. Two hundred grams of sample were put into a porcelain tray. Secondly, through 30 min deactivation of enzymes at $105{ }^{\circ} \mathrm{C}$, the samples were dried to constant weight in a $50{ }^{\circ} \mathrm{C}$ blast box and taken out to crush through a 60-mesh nylon sieve for use. Lastly, the screened samples were blended evenly and put into a brown bottle for sealed storage. Meanwhile, these samples were tagged and numbered to determine subsequently. Chosen were 40 grams of them through the dry ashing method and extracted with hydrochloric acid dissolving. The samples were determined by the graphite furnace method with TAS-986 type atomic absorption spectrophotometer.

In order to control the pre-treatment of samples and analysis quality of instruments, the paper chooses the standard samples corresponding to the national level (GBW07604) for reference to assess the accuracy of the analytical process. The findings show that the recovery rate is $88 \%$ and the analysis is effectively controlled.

\section{Results and discussion}

According to the findings on $\mathrm{Cd}$ content of the different parts in woody plants, this study, based on statistical methods, carries out the analysis of migration law of $\mathrm{Cd}$ content in different parts through the multiple model trend analysis method. The analysis is linear and logarithmic, and performed from the aspect of conic curve, cubic curve, compound curve, exponential, S curve, growth and exponential regression model, in order to determine the en- richment characteristics of the heavy metal $\mathrm{Cd}$ in woody plants. Through a variety of trend fitting analyses, the results suggest that only the degree of fitting of cubic curve model is relatively high. The statistical results of the degree of fitting are shown in Table 1, and the enrichment characteristics of $\mathrm{Cd}$ in different parts of different woody plants are shown in Fig. 1.

Table 1 - Statistical results of cubic curve model fitting degree Tablica 1 - Statistički rezultati za kubni model

\begin{tabular}{|c|c|c|c|}
\hline & \multicolumn{3}{|c|}{$R^{2}$} \\
\hline & $>0.9$ & $0.8-0.9$ & $<0.8$ \\
\hline $\begin{array}{l}\text { Tree species } \\
\text { Vrste drveća }\end{array}$ & \multicolumn{3}{|c|}{$\begin{array}{r}\text { Statistical results } / \% \\
\text { Statistički rezultati/\% }\end{array}$} \\
\hline $\begin{array}{l}\text { poplar } \\
\text { topola }\end{array}$ & 87.5 & 12.5 & 0 \\
\hline Ligustrum lucidum & 86.6 & 13.4 & 0 \\
\hline Sichuan juniper & 80.0 & 10.0 & 10.0 \\
\hline Cedrus deodara & 77.8 & 11.1 & 11.1 \\
\hline $\begin{array}{l}\text { average } \\
\text { prosječno }\end{array}$ & 83.0 & 11.7 & 5.3 \\
\hline
\end{tabular}

According to Table 1, cubic curve model fitting degree of heavy metal $\mathrm{Cd}$ in the different parts of woody plants is higher. The fitting degree $R^{2}$ is mainly distributed from 0.8 to 1 , accounting for about $94.7 \%$ within the range. Only the degrees of fitting for individual trees are lower than 0 . The fitting effects of Poplar and Ligustrum lucidu are the best, and their fitting degrees are both higher than 0.8. The degrees of fitting of the two kinds of trees that are higher than 0.9 , account for about $87.5 \%$ and $86.6 \%$, respectively. Therefore, the enrichment characteristics of $\mathrm{Cd}$ in different parts of woody plants in the root-stem-branchleaf sequence correspond to the cubic curve law.

In Fig. 1, the enrichment characteristics of $\mathrm{Cd}$ in woody plants are shown as follows. Firstly, the distribution of $\mathrm{Cd}$ in Poplar is mainly enriched in branches and leaves. The enrichment content in rhizome is the lowest, and Cd is enriched in the order of rhizome-branch-leaves. The enrichment content shows an increasing tendency. Secondly, the distribution of $\mathrm{Cd}$ in Ligustrum lucidu is mainly in the leaves, which is almost the same as that of $\mathrm{Cd}$ in the roots, stems and branches. In addition, $\mathrm{Cd}$ is distributed in order of roots, stems, branches and leaves, and the enrichment content increases gradually. Thirdly, the distribution of $\mathrm{Cd}$ in Sichuan juniper is mainly in the stems at around $120 \mathrm{~cm}$, and the enrichment content shows an increasing tendency along the stems, lowest in rhizome, reaching a peak in the stems at around $150 \mathrm{~cm}$. Lastly, the distribution of $\mathrm{Cd}$ in Cedrus deodara is mainly in the stems at around $150 \mathrm{~cm}$ and the branches, and enrichment content increases gradually along the stems, reaching a peak in the stems at around $150 \mathrm{~cm}$. 

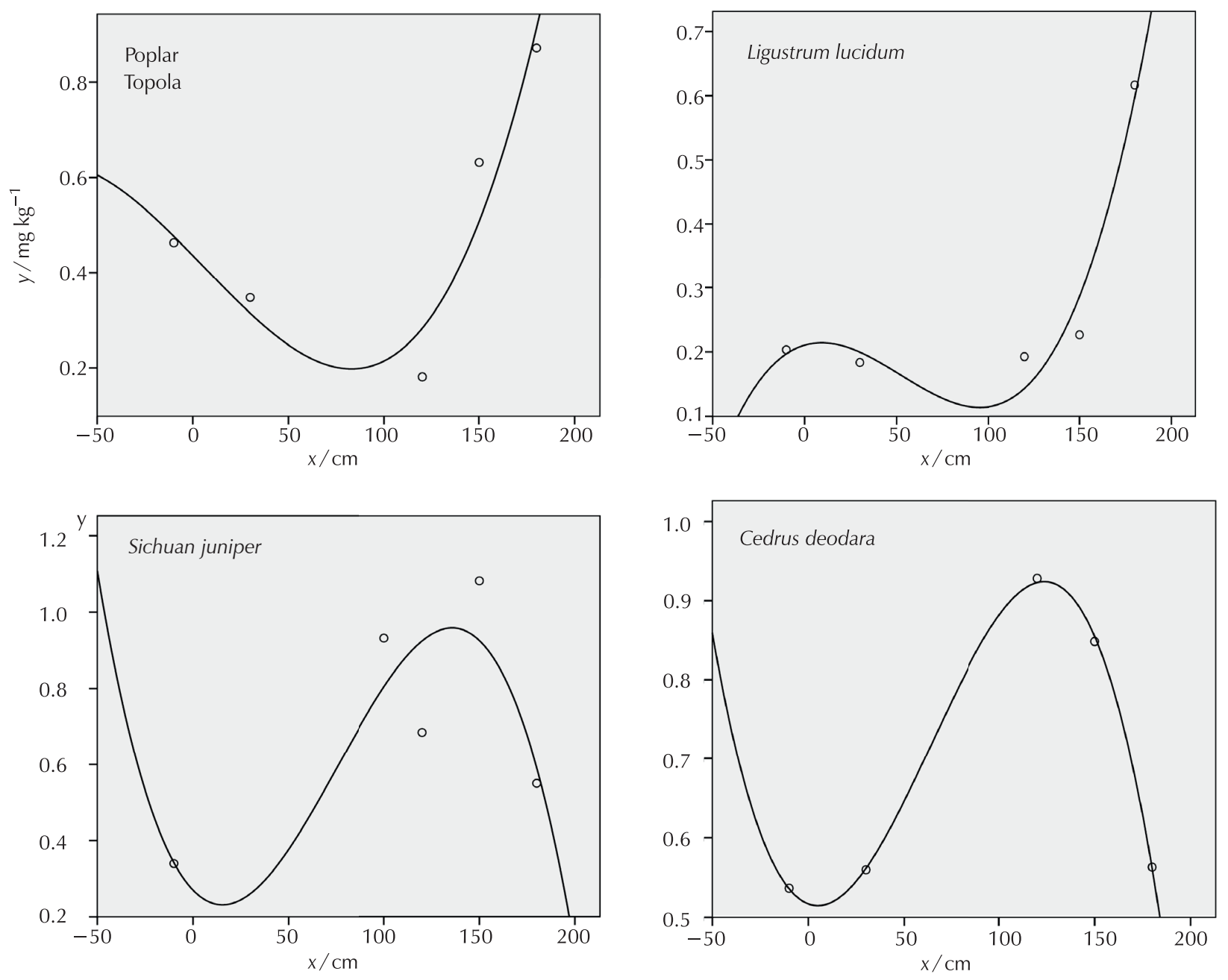

Fig. 1 - Enrichment characteristics of $\mathrm{Cd}$ in woody plants Slika 1 - Nakupljanje kadmija u drvenastim biljkama

\section{Conclusions}

Through model trend fitting of $\mathrm{Cd}$ content in the different parts of different species, the enrichment characteristics of $\mathrm{Cd}$ in different woody plants along roots, stems, branches and leaves correspond to the cubic curve model, and the degree of fitting is higher. Therefore, the enrichment characteristics of heavy metal $\mathrm{Cd}$ in different woody plants along the root-stem-branch-leaf are as follows: $y=b_{3} x^{3}+b_{2} x^{2}+b_{1} x+b_{0}$. In the formula, $y$ represents the heavy metal $\mathrm{Cd}$ content in different parts of woody plants, $\mathrm{mg} \mathrm{kg}^{-1} ; \mathrm{x}$ represents different parts of woody plants, standing for the distance, $\mathrm{cm}$. This shows that heavy metal $\mathrm{Cd}$ is enriched in order of roots, stems, branches and leaves in the form of cubic curve. The enrichment capability of $\mathrm{Cd}$ in various parts of different woody plants is different, and so is the capacity in different parts of the same kinds of woody plants.

When studying the $\mathrm{Cd}$ enrichment characteristics in the woody plants system, we should consider the characteristics of the heavy metals and plants comprehensively, such as the types, concentration and existing forms of heavy metals, as well as the species, growth, reproduction and subcellular structure of plants, etc. Therefore, future research should be focused on the distribution characteristics of heavy metals in different existing forms during the different plants growth periods, which provides the scientific evidence for the popularization and application of phytoremediation technology, as well as the control of heavy metals pollution.

\section{List of symbols and abbreviations Popis simbola i kratica}

$R^{2}-$ correlation coefficient

- koeficijent korelacije

y - Cd content in different parts of woody plants, $\mathrm{mg} \mathrm{kg}^{-1}$

- sadržaj kadmija u različitim dijelovima drvenastih biljaka, $\mathrm{mg} \mathrm{kg}^{-1}$

$x$ - distance of different parts of woody plants, $\mathrm{cm}$

- udaljenost dijelova drvenastih biljaka, $\mathrm{cm}$ 


\section{References \\ Literatura}

1. Y. S. Chen, R. J. Wu, J. Zhuang, F. F. Chen, H. J,. Heavy metal toxicity and resistant mechanisms in woody plants, J. Fujian Forestry Sci. Techn. 34 (1) (2007) 5055.

2. N. W. Lepp, Effects of heavy metal pollution plants. London, Applied Science publishers 12 (2) (1981) 25-29.

3. G. Y. Yu, Y. S. Wu, H. X. Wang, Effects of the differential Cd compounds and their interaction on the wheat, J. Acta Ecologica Sinica. 12 (1) (1992) 93-96.

4. S. Wei, Q. X. Zhou, Discussion on basic principles and strengthening measures for phytoremediation of soils contaminated by heavy metals, Chinese J. Ecol. 23 (1) (2004) 65-72.

5. T. Punshon, N. W. Lepp, N. M. Dickinson, Resistance to copper toxicity in some British willows, J. Geochem. Explor. 52 (1995) 259-266, doi: http://dx.doi. org/10.1016/0375-6742(94)00048-G.

6. T. Granel, B. Robinson, T. Mills, B. Clothier, S. Green, L. Fung, $\mathrm{Cd}$ accumulation by willow clones used for soil conservation, stock fodder, and phytoremediation, J. Soil Res. 40 (8) (2002) 1331-1337, doi: http://dx.doi. org/10.1071/SR02031.

7. G. Y. Yu, Y. Y. Wu, X. Wang, Transferring and cycling of heavy metals in and out of Poplar tree before and after its leaf fallen, J. Chinese Journal of Applied Eco. 7 (2) (1996) 201-208.

8. X. Li, D. M. Xu, Y. C. Zhao, D. X. Niu, B. Li, Z. Y. Li, X. J. Sun, L. Xiong, . Distribution of heavy metals in cover soil and vegetation of closed sanitary landfill, Environ.
Pollut. Control 28 (9) (2006) 641-670.

9. Z. G. Zhang, D. X. Yao, Y. H. Zheng, The phytoremediation potential of six compositae plants to soil pollution of heavy metal in coal mine collapse and reclaimed area, J. China Coal Soc. 35 (10) (2010) 1742-1747.

10. D. Hammer, A. Kayser, C. Keller, Phytoextraction of $\mathrm{Cd}$ and $\mathrm{Zn}$ with Salix viminalis in field trials, Soil Use Manage. 19 (3) (2003) 187-192, doi: http://dx.doi. org/10.1111/j.1475-2743.2003.tb00303.x

11. C. Cobbett, Heavy metals and plants-model systems and hyperaccumulators, New Phytologist 159 (2) (2003) 289-293, doi: http://dx.doi.org/10.1046/ j.1469-8137.2003.00832.x.

12. I. D. Pulford, C. Watson, Phytoremediation of heavy metal-contaminated land by trees-a review, Environ. Int. 29 (2003) 529-540, doi: http://dx.doi. org/10.1016/S0160-4120(02)00152-6.

13. J.-X. Yang, Z.-G. Zhang, Y.-C. Chen, The Study on Soil Improvement by Greening Tree Species in Coal Mine Reclamation Area, Proceedings of the $3^{\text {rd }}$ International Conference on Environmental Technology and Knowledge Transfer 5 (2010) 221-224.

14. A. Samecka-Cymerman, D. Stepien, A. J. Kempers, Efficiency in removing pollutants by constructed wetland purification systems in Poland, J. Tox. Env. Health A 67 (4) (2004) 265-275, doi: http://dx.doi. org/10.1080/15287390490273532.

15. I. Laureysens, L. D. Temmerman, T. Hastir, M. Van Gysel, $R$. Ceulemans, Clonal variation in heavy metal accumulation and biomass production in a Poplar coppice culture. II. Vertical distribution and phytoextraction potential, Environ. Pollut. 133 (3) (2005) 541-551, doi: http://dx.doi.org/10.1016/j.envpol.2004.06.013.

\section{SAŽETAK \\ Obogaćivanje kadmijem u drvenastih biljaka \\ Jin Xiang Yang, Xiao Long Li,* Youbiao Hu, Liang Min Gao i Duo Xi Yao}

U posljednjih nekoliko godina provedena su opsežna istraživanja u području fitoremedijacijske tehnologije, no vrlo su rijetka istraživanja vezana uz migracijske putove teških metala u drvenastim biljkama.

Predmet istraživanja bilo je područje rudnika Pan Yi u Huainanu kao primjer područja sa sadržajem kadmija u različitim dijelovima tkiva drvenastih biljaka. Temeljem rezultata istraživanja o migracijskom putu, rad se koristi statističkim metodama provođenjem analize putem višestrukog modela. Statističke metode uključivale su višestruke analize trenda: linearnu i logaritamsku, a također analize s aspekta konika, kubne i složene krivulje, eksponencijalne, S-krivulje, modela rasta i eksponencijalne regresije. Rezultati pokazuju da se kadmij nakuplja duž sustava korijen-stabljika-grana-list u drvenastoj biljci u prema funkciji $y=b_{3} x^{3}+b_{2} x^{2}+b_{1} x+b_{0}$. Rezultati dodatno otkrivaju da je sposobnost obogaćivanja kadmijem drugačija u različitim dijelovima iste vrste drvenastih biljaka, a to je slučaj i u različitim vrstama biljaka.

Ključne riječi

Teški metali, kadmij, drvenaste biljke, obogaćivanje

The School of Earth and Environment Anhui University of Science and Technology 232001 Huainan Anhui Kina
Prethodno priopćenje Prispjelo 31. prosinca 2014. Prihvaćeno 18. ožujka 2015. 